\title{
From Westphalian Failure to Heterarchic Governance in MENA: The Case of Syria
}

\author{
Raymond Hinnebusch \\ University of St Andrews, $\underline{\text { rh10@st-andrews.ac.uk }}$
}

\section{Small Wars and Insurgencies}

April 2018

https://doi.orq/10.1080/09592318.2018.1455330

\begin{abstract}
The problematic export of the Westphalian system to MENA is examined, taking Syria as exemplar. The export model is juxtaposed to actual non-lineal trajectories, semisovereignty and hybrid or failing states. This is manifested in post-uprising Syria in failing statehood, fragmented and overlapping governance, permeable and collapsing borders, the loss of sovereignty to trans-state movements, "competitive regime-building" between the Asad regime and jihadist warlords, and "competitive interventionism" by external powers filling the governance vacuum with their own proxies. The result is heterarchic zones of limited statehood in which state sovereignty is contested by both international (supra-state) penetration and sub-state fragmentation.
\end{abstract}

Key words: state failure, heterarchy, Middle East, Westphalian order, civil war, governance, hybrid regimes, Syria

The Westphalian system was supposedly exported to the MENA under Western imperialism and adopted with alacrity by state builders. Yet in MENA it has only ever been at best approximated and only for limited periods, reaching its peak in the 1980s, declining thereafter and reaching a nadir after the Arab uprising (2010- ) when multiple state failures rippled across the region. In several areas, the Westphalian model seemingly collapsed, giving way to heterarchic zones of limited statehood in which the sovereignty of states was contested by both international (supra-state) penetration and sub-state fragmentation. This paper tries to understand why the outcome of Westphalian "export" reached the point of state failure in multiple cases and the heterarchic forms of governance that have replaced-or, more accurately, are contesting-the remnants of the Westphalian system.

The first part of the paper recounts the Westphalian export narrative, and shows why and in what way a flawed, even perverted, Westphalian system made up of weak penetrated states, always vulnerable to failure, was exported to MENA. The second part of the paper shows that the vacuum of authority following state failure was filled by new "heterarchic" forms of governance. The argument is demonstrated in the case of Syria, which exemplifies such forms of governance in their starkest form. Here the collapse of Westphalian statehood was manifested in the state's loss of territorial and border control, and penetration by trans-state movements, accelerated from without by the violation of Syria's sovereignty by regional and international powers; in this vacuum, governance, is fragmented, overlapping, informal and violent.

\section{Export of a Flawed Westphalian States system}

The export of the Westphalian states system -i.e. Weberian states congruent with a national community (nation-states) that mutually recognize each other's sovereigntyto the non-Western world, including MENA, is widely assumed. It is implicit in Realism's 
assumption of a globalized "anarchic" (no central governance) system of equally sovereign states. The export process is explicitly recounted in the International Society literature (Bull and Watson 1984; Buzan and Little 2010;). In a first movement, Western imperialism constituted "states" from above-mere territorial "shells" suiting their geopolitical interest; in a second movement, after de-colonization indigenous state builders tried to fill these shells with content-Weberian institutions, national identities. This is because nation-states were perceived to be the most effective model of governance: the more the incongruence of state and nation, the more the legitimacy deficit and the greater vulnerability to separatism and irredentism; while the greater the congruence, the better states could nationally mobilize their populations so as to compete in the international power struggle (Smith 1981; Gellner 2006). For Realists and World Polity theorists, state builders, "socialized" into the rules of international politics, tried to emulate the internationally successful Westphalian nation-state (Waltz, 1979; Meyer et.al; 1997). In MENA this began with Ottoman "defensive modernization" and came best to be exemplified in Ataturk's forging of a Turkish nation-state out of Ottoman ruins. Arab leaders who inherited states in the former Ottoman domains faced the greater obstacle of Western-imposed arbitrary borders cutting across identity fragmented societies, but, similarly, sought to forge the nation from above accompanied by Weberian state centralization of power, Yet, with the Arab Uprisings, that project apparently ended in spectacular failure in many MENA states. This is not entirely inexplicable for it was by no means inevitable that Westphalia would effectively "take" outside the West where it originated. Indeed, it is generally acknowledged that it has always been a normative construction in global discourse or an Weberian ideal type in scholarly analysis, often violated or much diluted in practice (Krasner 1999; Risse 2013). However, the actual deviation from the ideal type has grown increasingly obvious, particularly in the current Middle East, for several reasons and as exemplified in several phenomena.

Identity/Territorial Incongruity: First, the outcome of Westphalian export in MENA lacked the apparent legitimacy benefits of a nation-state system. In this arid region of trading cities and nomadic tribes, the strongest identifications attached to sub-state units-cities, tribe, religious sects-or the larger Islamic umma; Islamic empires built on these identities and since their boundaries fluctuated greatly as they rose and fell, identifications with territorial states were tepid (Weuleresse 1946: 79-83). But equally important, arbitrary Western imposition of boundaries erected major additional obstacles to the nation-state model. The incongruence between the territorial states and pre-existing supra and sub-state identities, exacerbated by arbitrary boundary imposition cutting across identity fragmented societies, was especially marked in the Arab mashreq where, following the infamous WWI "Sykes-Picot agreement," the dismantling of historic Syria led to a continuing contestation of state legitimacy by competing supra- and sub-state identities. This kept states vulnerable to internal insurgency, irredentism, and trans-state interference. Thus, what was exported to the region were initially quasi-states, in Jackson's (1993) term, arguably, set up to fail but nevertheless sustained by international guarantees against absorption by stronger regional powers - thus, sustaining a system of weak states as Lustik (1997) argued.

Hybrid power technologies: Once post-decolonization indigenous state-builders sought to enforce effective sovereignty, they adapted imported Weberian political technology to indigenous political culture, resulting in hybrid outcomes (Bacik 2008). For Weber, indeed, modern "legal rational" authority was only the end point of a long evolution and in pre-modern periods of "primitive power accumulation" other forms of authority had dominated, namely, the charismatic and the patrimonial, ideal types inspired by 
Weber's reading of Ibn Khaldun, the "father of sociology." When the Weberian rationallegal model was exported to regions still engaged in this power accumulation, the region's historically proven Khaldunian power building practices would, as path dependency suggests, inevitably get reproduced; when combined with partly"imported" bureaucratic practices, the result would be hybrids such as neopatrimonialism. Such a formation, benefiting from its congruence with widely understood historic practices, may be quite robust for extended periods of time; but since charismatic and patrimonial authority, as Ibn Khaldun showed, inevitably decline-so also will neo-patrimonial regimes unless this is counter-acted by the development of the rational institutional side of the regime. Indeed, over the long term, the more mobilized societies that accompany socio-economic modernization cannot be effectively governed without this corresponding political modernization (Bank and Richter 2010)—which, however, tended to lag behind societal mobilization.

Semi-sovereignty to neo-medievalism: far from seeking to export sovereign states, the Western core powers, in fragmenting the Middle East into a multitude of weak states, actually sought to establish a hierarchy in which MENA states inhabited the bottom rungs. The sovereignty of such weak states was (as Krasner (1999) argued in calling sovereignty "organized hypocrisy") frequently violated by the military intervention of the core states. During the Cold war nationalist movements took power across the Middle East and took advantage of great power rivalries to gain, for a period, greater sovereignty. Subsequently, however, the core has sought to reverse this diffusion of power to the periphery and re-constitute periphery states as merely semi-sovereign (Clark 2001). First, without countervailing Soviet power, military intervention against defiant nationalist regimes took the extreme form of state deconstruction-e.g. the Iraq war, intervention in Libya. Second, globalization turned regional states into transmission belts of neo-liberalism (Cox 1996). This has encountered resistance from victimized underclasses mobilized via either supra-state ideologies such as Islamism, or fragmenting ethnic and religious identities (Barber 1995), catching the state in a pincer movement from above and below. The result of globalization is a certain reversal of Westphalian order, in which states are everywhere ceding authority to supra and substate levels in what Bull (1995: 254-55) called Neo-Medievalism; however this happens very unevenly and most intensely in the weak states of the global periphery. Thus, rather than a simple export of Westphalian sovereignty to the periphery, the actual degree of sovereignty acquired by MENA states has been the outcome of an on-going struggle between Western penetration and resistance/collaboration by states and movements in the periphery.

Non-linear trajectories: for all these reasons, state formation in the region has described, not a progressive approximation of the Westphalian state system, but a bell-shaped curve in which state-builders' attempts to approximate it reached, from a starting point of very weak statehood, a peak and then went into decline, a process co-constituted by the interaction of global level forces (constraints, intervention, resources) and regional state building projects. From the 1960s, rent from both great power patrons and the oil boom enabled consolidation of more inclusive forms of neo-patrimonialism based on a populist-nationalist social contract, notably in the republics. However, by the nineties state decline had set in, corresponding to neo-liberal globalization under US hegemony, which, combined with falls in rent, propelled a retreat in MENA states' inclusiveness under pressure from IMF-promoted "structural adjustment" and the rise of crony capitalism (empowered by IMF-imposed privatizations of public sectors). While authoritarian regimes proved quite resilient in adapting to neo-liberalism, e.g. creating crony capitalist support and off loading welfare responsibilities to Islamists, under the 
surface the seeds that would drive the Arab uprising were being planted. Arab authoritarian republics, in particular, experienced a destabilizing combination of Western export of neo-liberalism that narrowed the basis of their rule with democracy campaigns that de-legitimized them as they reneged on the populist social contracts on which they had built their social bases. The victims of neo-liberalism withdrew their loyalty from the state and attached it to sub/trans-state movements and identities, Islamism, sectarianism, and ethnicity. Thus, as state's strength declined, so correspondingly did their penetration by global forces and vulnerability to mobilizing sub/trans-state movements relatively increase.

Failing Statehood, proxy wars: If the Weberian state is the apex of Westphalian order, its nadir is the failed state. Far from an anomaly, failed states have come to constitute a fifth of world states (40 out of 200), marking a transition, Edward Newman (2009) suggests, to a post-Westphalian world where sovereignty gives way to intervention and wars are intra- rather than inter-state. This wave of state failure is widely attributed to the pincer in which states are caught of globalization from above and resistance (jihad) to it from below by fragmenting identity movements. MENA states, especially those in the Arab mashreq, were, owing to their initial identity/territory incongruence and potential neopatrimonial decline, especially vulnerable. But it took precipitating factors at the international level to tip weak states into failed ones: Iraq's deconstruction by the combination of US invasion and sectarian civil war within, set off regional destabilization; and once civil conflict broke out in several states, competitive interference by global and regional powers resulted in proxy wars further driving state failures.

Heterarchic Non-Westphalian Governance: State failure does not mean a lack of governance, nor the replacement of formal hierarchy by anarchy; rather the vacuum it leaves is rapidly filled by multiple competing actors with authority over limited areas, none of which are able to re-establish state-wide Weberian hierarchy-a situation of heterarchy (Donnelly 2016), or "oligopoly of violence" in which some contenders establish enough local "order" to mute or contain violent anarchy and within certain areas sufficient predominance that "limited statehood" (Risse 2013) may be said to prevail. Power is contested or jurisdictions shared between the remnants of the preexisting regimes and rebel governance, global and regional interventionists and newly empowered trans-state social movements. Hybridity results from the interaction of "traditional" and "modern," formal and informal, local and international (McGinty 2011). This governance is fragmented, informal, grassroots, fluid and often violent. The following account details this phase of state deconstruction in the Syrian case and the forms of hybrid governance that filled the vacuum.

\section{The Collapse of the Westphalian Project in Syria}

\section{Rise and Decline of the Ba'thist Regime}

State building under the Ba'th had consolidated the Syrian state along semiWestphalian lines, with the regime penetrating and integrating its territory and acquiring the capabilities to defend sovereignty from external threats. Indeed, Hafiz alAsad's power-building formula-the use of sectarian assabiya to create a loyal elite core in charge of the security forces combined with a mass-inclusive single party penetrating the villages and populist distribution (land reform)--produced a particularly robust form of neo-patrimonialism. While in the early independence years Syria had been notoriously vulnerable to external penetration, making it a battleground of rival external powers, by the seventies Asad had made Syria an actor on the regional stage (Hinnebusch 1990). 
The decline of this state building project came in parallel to its attempt to adapt to the neo-liberal world. The Syrian uprising was rooted in the ills of neo-liberal driven postpopulism: the enrichment of crony capitalists and the reneging on the social contract, shrinking social entitlements for the poor, and the consequent weakening of the Ba'th Party's co-optative capacity. The demonstration effect of the Arab uprising precipitated anti-regime protests in Syria, swelled by those aggrieved by post-populism in "undergoverned" areas-the rural migrants of the shantytowns and the neglected eastern provinces.

It was by no means inevitable that protests would lead to civil war and state failure. Why this happened is beyond the scope of this study, but very briefly: the regime's use of excessive violence against protestors only inflamed the uprising; the dominance of hard liners on both sides, precluding a transition pact, with sectarian discourses instrumentalized on both sides; the continued loyalty of the core security forces willing to use violence against protestors, combined with considerable defection from the army rank and file that organized into a counter-army (the Free Syrian Army); the militarization of the opposition and the regime's loss of control over more far-flung parts of the country, creating shifting front lines between regime and opposition control; and external intervention on behalf of the opposition and later to shore up the regime, which funnelled the arms and money to continue the conflict, followed by the arrival of foreign jihadists-all these factors drove Syria's trajectory of deepening conflict (Hinnebusch 2012; Hinnebusch, Imady, Zintl 2015).

\section{Civil War, State failure:}

Civil war and state failure paralleled and reinforced each other in Syria, manifesting all the features of Kaldor's (2005) "New Wars." Syria experienced what might be called a "double state failure" combining, at the material level, the state's loss of monopoly of violence and territorial control to non-state armed movements with, at the ideational level, a shrinking of inclusive identifications with the state and spread of rival sectarian narratives.

The latter was driven by a "security dilemma" (Posen 1993). Massive violence, with the regime use of heavy weapons against cities and car bombings by terrorists, combined with the widespread breakdown of order, precipitated reliance by people on local armed militias of their own identity group for protection. Local Warlords with sufficient armed capacity and a claim to defend their identity group emerged, ostensibly to fill the security gap but making all less secure. Episodes of sectarian cleansing and demonizing of the "other" at the grassroots led many Syrians to identify with fellow sectarians outside Syria rather that with other Syrians of different sectarian affiliations.

The widespread arming of self-defence militias and recruitment to fighting factions fostered what Abboud (2016: 85-86) called the "civilianization of war," as the proportion of the population engaged in violence dramatically expanded. This eroded the distinction between combatants and non-combatants and led to massive deaths, internal dislocation and cross border refugee flows.

\section{Fragmentation of "rebel governance"}

When the Syrian state failed, its administrative reach contracting from areas lost to opposition forces, the resulting "ungoverned space" was filled by informal, "rebel" or hybrid governance. The gap in service provision was initially filled by local councils born out of the local coordination committees that had organized anti-regime protests, 
as well as by civil society movements. Opposition activists saw this local governance as coming to constitute an institutional alternative to regime rule. However, it was highly localized, with coordination reliant on intermittently functioning networks, resulting in increasing fragmentation. This was exacerbated by regional level backing for rival groups and the third layer of "governance" by international donors who channelled funds, along with their own conflicting agendas, through rival external opposition groups or private sub-contractors (with the result that only a fraction of it reached the grassroots in Syria) (Khalaf 2015; Abboud 2016: 180-182).

Fragmentation was deepened by the militarization of the uprising. Initially, highly localized fighting groups arose to defend their own areas against regime violence and formed the armed wing of the local councils. Although repeated attempts were made to amalgamate these into a single opposition army, the Free Syrian Army, with a central command structure, these had limited success, partly because FSA HQ could not provide resources, and fighters had to rely on external funders who financed their own clients, encouraging splits between Saudi, and Qatari funded factions. In 2013, there were 1000 brigades and three thousand smaller units. They did periodically come together in "fronts" attempting coordination against the regime but often subsequently splintered and lacked any durable common strategy. Formations large enough to hold and expand territory did not, therefore, emerge as groups became satisfied with profiting from local fiefdoms. To the extent the FSA units became local warlords profiting on protection rackets, they lost their popular character (Abboud 2016: 81-95). Competition over control of lucrative checkpoints and oil resources became a frequent source of opposition infighting. The FSA was so dependent for funding by external sponsors via Turkey and Jordan that these two countries were able to turn its factions into their proxies fighting, not Asad, but the enemies they had inadvertently created by their original attempt to destabilize Asad-the Islamic State and, for Turkey, the Kurdish Democratic Union Party (PYD) (LeGrande 2016). Another force of fragmentation was the increased Islamization of the fighting groups and indeed the rise of jihadist movements that saw the FSA as a rival and frequently attacked it; moreover, Islamist movements injected ideological rivalries into the opposition, which often resulted in inter-Islamist splits. Thus, IS and Jabhat al-Nusra started as affiliates of al-Qaida in Iraq, but split and the first battles of IS in Syria were with Nusra and other Islamists for domination, starting with its seizure of Raqqa from the former. The most successful jihadist "front," that formed from an alliance of Nusra and Ahrar ash-Sham, the "Army of Conquest" that captured Idlib in 2015, had by 2017 broken up as the former turned on and defeated the latter. At the same time, the threat of jihadists to the religious and ethnic minorities led to their establishing protective militias, also contributing to fragmentation, with the PYD the most successful of these. This fragmented (and reciprocal mobilization), left everybody, less, not more secure (Abboud 2016:97-108, 162-87; Lawson 2014). The result was that the conflict became a war of attrition in which advances by both sides were incremental and difficult to hold, leading to a patchwork of control among a multitude of groups.

Further reinforcing fragmentation was the shrinking of the normal economy as the national market disintegrated and internal trade barriers sprung up, controlled by fighters levying taxes on the flow of goods. At the same time, the fragmented regions were more intensely linked economically to the outside of Syria than hitherto. Abboud (2014) argues that as internal production declined, the inward flows of resources, including humanitarian aid and funding from opposition sponsors, became the main prizes over which rivals struggled. In parallel, as civil war made normal economic life more precarious, young men became dependent on salaries from armed groups 
dominated by localized warlords who resorted to smuggling, kidnapping and taxation of goods at checkpoints, as well as external funding and which therefore had an incentive to keep the fighting going. The most militant jihadist groups expanded at the expense of the FSA because they had access to superior funding from external patrons or were more able to seize resources, such as oil fields (Abboud 2014, Yaziji 2014, Turkmani 2015). In places under siege, pro and anti government armed groups used check points to extract resources from the population in a process that redistributed wealth from the poorest to a new war rich (Todman 2016).

\section{Overlapping Governance}

A key feature of hybrid governance is overlap in the jurisdiction of rival authorities. In Syria such overlap has been a constant feature. In the early years of the uprising, government officials delivering key services in opposition areas continued to be paid salaries by the central government, which sought to depict itself as the legitimate state on which citizens were reliant for basic services. In Kurdish areas, PYD and Syrian government officials co-existed, with the regime officials and school curriculum carrying on in the main cities even after the army withdrew. In Manbij opposition locals asked government officials to keep working and they continued to be paid by the regime: the government land registry personal continued operation and electricity, water and local flour mills were run by paid government officials. The overlap between regime and opposition jurisdictions challenges the over-simplicity of a regimeopposition dichotomy (Ali 2015)

Much later in the uprising, a growing wave of truces or de-escalation zones between regime and opposition led to a patchwork of power-sharing arrangements on the regime/opposition front lines. The regime, facing manpower shortages that precluded the re-conquest of opposition areas, resorted to imposing settlements, piece by piece, via bombing and/or sieges, on the margins of government controlled areas. In the Damascus area, for example, the regime benefited from the opposition's fragmentation, inability to coordinate combined offensives and vulnerability to being picked off one by one. Populations became alienated as opposition fighters failed to shield people from the regime's sieges and air assaults as well as by their infighting over control of supplies and access points, personal power and doctrinal differences (among Islamists); it was often popular pressure on the fighters that led them to accept truces with the regime (Glass 2017; Lund 2017a).

The extent of overlapping jurisdiction varied widely according to the particular deal negotiated, itself a function of the power balance between the sides. Under one type of deal, such as that reached in Barzeh in 2014, rebels maintained control of their areas in return for handing over heavy weaponry and halting attacks on regime forces; in return, sieges were lifted, return of the displaced allowed and public utilities restored (Hamlo 2015). In Dera muhafazat, much of the town of al-Sanamayn had fallen out of regime control and opposition local councils were set up, though most of the public services were still provided by the regime. The regime laid siege to the opposition-controlled neighbourhoods, which was lifted under an agreement that the rebels would not attack regime positions or personnel. Some (not all) weapons were handed over but opposition fighters continued to control much of the town while regime security forces remained on the outskirts (al-Tamimi 2017). 
While Syria's borders had always had a certain permeability, when there was a strong regime (1970-2000) they hardened significantly. With state failure, however, the country was open to penetration as never before. Legally, borders remained recognized by the international community but defacto they were now routinely violated by external powers. Even as Syria fragmented within and new defacto internal borders arose on the frontlines controlled by armed groups and checkpoints, the government lost control of its many of its external borders, leading to increased interconnectedness across them (DelSarto 2017), seen in the flow of resources, fighters and refugees, to and from neighbouring countries. Syrian activists in neighbouring countries or further abroad networked into and supported opposition areas as well as remaining connected with the country via virtual (internet) communities (Hamdan 2017).

Control of borders was a strategic asset for opposition factions and Syria's borders were fragmented into segments controlled by rival groups. Border control was crucial to taxing, controlling the flow of humanitarian aid, oil, fighters, smuggled goods and weapons into Syria from outside funders, NGOs and states, as well as export of such commodities as oil. Battles took place over supply routes, e.g. the Kurdish-dominated Syrian Democratic forces (SDF) took Manbij to cut off IS access to Turkey and Turkey launched Euphrates Shield in August 2016 both to dislodge IS from Jarabalus and to prevent the Kurds from linking up their western and eastern cantons on the border. Syria's borderlands-boundaries in depth-became, as the state's control contracted, areas of contestation in which tribes and trans-state movements were empowered and safe havens for fighters and platforms for international NGOs were concentrated. The opposition fighters depended on safe havens-rear bases, training facilities-near the Turkish and Jordanian borders. Syria's neighbours selectively softened and hardened the borders, seeking to both intervene in the conflict yet prevent spillover and blowback. Thus, Turkey opened its border to refugees, provided a safe haven for opposition fighters, and allowed IS to transit fighters and oil flows across its borders; but when IS turned against it, and refugees flows became too onerous, Turkey hardened the border, building a wall in places and stopping the easy flow of refugees and fighters (Vignal 2017; Lund 2017b; DelSarto 2017; Khateb 2017b).

\section{Rising trans-state actors, merging political space, border-busting projects}

The failure of states and the rise of armed non-state actors made Syria and Iraq an interconnected field of contestation in which trans-state groups moved back and forth as the power struggle dictated, contesting state borders and sovereignty in an utterly unprecedented way.

The Syria conflict rapidly spilled over as Iraqi actors took sides in Syria, symptomatic of the trans-state identities linking the two states. Euphrates Valley tribes from Iraq's Anbar province sent money, weapons and thousands of fighters to support their antiAsad Syrian cousins in Deir al-Zur (Knights 2012); with historic familial and financial links to ruling elites in the Gulf states, cross-border tribes were conduits of Riyadh's anti-Asad policy and of arms deliveries to the Syrian insurgents. The fighting in eastern Syria also spilled over in Iraq when Syrian insurgents attacked Syrian regime forces taking refuge on Iraqi soil, even killing Iraq troops (Knights, 2012; El-Hamed 2013).

As the Syrian conflict turned into civil war the Syrian opposition took on an ever more jihadist flavour that operated trans-state, seeing the struggles against non-Sunni rule in Iraq and Syria as inseparable. Thus, Iraqi Sunnis jihadists from Mosul joined the Syrian Jabhat al-Nusra and passed on their technology of car bombings and IUDs learned in the Iraqi insurgency. Syria's Jabhat al-Nusra declared that "fighting against the Shiite Iraqi government in Baghdad is a jihad and sacred religious duty in order to liberate it from 
the Magi" (i.e. Persians) (El-Hamed 2013). Giving a yet greater trans-state sectarian dimension to the struggle was the internationalization of the Syrian conflict as Sunni jihadists from outside the Levant flocked to Syria to fight the Asad regime, particularly recruited by the two trans-state al-Qaida avatars, Jabhat al-Nusra and IS. By 2015, around 27,000 Sunni foreign fighters from 86 countries were fighting the regimes in Iraq and Syria, with 16,000 from MENA, 5,000 from Europe, and 4,700 from former Soviet republics (Guardian 8 December 2015), many of them armed or given transit routes into Syria by the Sunni powers opposed to Asad-Turkey, Saudi Arabia, Qatarand funded by rich nationals of the Gulf states.

In reaction to this, Lebanon's Shia Hezbollah movement increasingly intervened on behalf of the regime, a strategic ally against Israel. Iran mobilized Iraqi and Afghan Shia militias to protect Shia mosques and communities near Damascus after jihadist attacks on the Sayyida Zaynab mosque which had fed a narrative that the Shia were on the defensive against Sunni takfiris who considered Shiites as heretics liable to be killed. However, the Iraqi Shia militias soon became involved on the side of the Syrian regime at a time when it was very much on the defensive, with some 5000-10,000 fighting alongside Hizbollah and contributing materially to tilting the power balance back toward the regime, particularly at the 2013 battle of Qusayr (Tamimi, 2015). While in 2012 Iraqi Shia militias had been reluctant to be seen to "intervene" in Syrian affairs (alSalhy 2012), by 2014-15 they boasted of it, as the two countries were now considered parts of an inseparable regional conflict stretching from Yemen to Lebanon. Hardened and zealous veterans of urban warfare, Shia militiamen soon became shock troops spearheading Syrian regime offensives against Sunni insurgents. When, with the IS conquest of Mosul, many Shia militias fighting in Syria returned to Iraq to counter IS, leaving Asad with an acute manpower problem, Iranian Quds commander, Qasem Soleimani, replaced them with Afghan Shia fighters. At the same time, Iran and Hizbollah helped incorporate the plethora of pro-regime local militias, whether Shia, Christian or other, into the regime's National Defense Force, trained and advised by Hizbollah and Iranian Revolutionary Guard officers, thereby propelling a certain "Shiaization" of Asad's decentralizing regime. This spurred increasing resentment among the opposition in Syria: a Syrian jihadist website warned the Shia in Syria: "This land is forbidden to you. This is the land of Omar and Abu Bakr" (Bulos 2017). Thus, a trans-state arena of conflict, represented as a regional sectarian battle and embracing the whole Levant, had eclipsed state-bounded ones

As state failures opened the door to the rise of powerful trans-state/non-state movements, the permanence of borders and the sovereignty of the states came under threat, portending a possible remaking of the states system (Stanfield 2013). While only a minority in Iraq and Syria wanted a re-drawing of the boundaries of their states, armed trans-state movements took advantage of the debilitation of states' territorial control to advance boundary-busting projects.

The Syrian uprising strengthened the Kurds' national and separatist ambitions. Syrian Kurdish regions became effectively autonomous of Damascus under the PYD, in parallel with the more consolidated autonomy enjoyed by the Kurdish Regional Government in Iraq. The PYD derived legitimacy from the relative order it introduced into Kurdish areas, its ability to defend the Kurds against IS as well as posing as protector of Arab moderates and minorities against jihadists. The PYD project did not reject the Westphalian system, per se, only the boundaries that had denied the Kurds nationstatehood after WWI. Officially aiming for autonomy within Syria, it did not even overtly challenge Syrian sovereignty, merely "softening" it; assuming, however, that its long- 
term goal was an independent Kurdistan, it could be said to seek to join the Westphalian system, not overthrow it.

Very different was the Islamic State (IS) project. The collapse of Syrian and Iraqi state control over their territories allowed IS to seize control over wide areas of western Iraq and eastern Syria, declaring the abolition of the Syrian-Iraq border as part of the construction of a transnational "Caliphate," explicitly touted as overthrowing "SykesPicot." Its legitimacy was based on an explicit rejection of Westphalian state boundaries in favour of endless expansion within the dar al-harb. IS originated as al-Qaida in Iraq (AQI), which grew up in the anarchy created by the US destruction of the Saddam Hussein regime. When AQI was defeated by the US in Iraq its remnants found safehaven in Syria and the later collapse of Syrian state control over eastern parts of the country allowed it, now rebranded Islamic State of Iraq and Sham (ISIS), to seize Raqqa and other parts of the east of the country. Indicative of the high level of inter-state permeability was the penetration by ISIS fighters as far west as Lebanon. Truly transnational, ISIS was a coalition including AQI, ex-Iraqi Ba'thists made jobless by the US occupation and legions of Sunni "foreign" fighters who flocked to Syria. In 2014 ISIS seized Mosul and proclaimed a caliphate straddling western Iraq and eastern Syria, shortening its name to Islamic State (IS). Having previously faced opposition in Syria from more Syria-centric elements of the Islamic opposition, including al-Qaida avatar, Jabhat al-Nusra, IS turned the momentum acquired in Iraq after Mosul (and the heavy weapons captured from the Iraqi army), to surge back across the border and put its Syrian rivals on the defensive. It benefited from the bandwagoning of disparate Syrian Islamist groups opposed to Asad who pledged fealty: some embraced IS because it had superior financial and military resources provided by Gulf donors or seized from the failing Iraqi and Syrian states while others submitted out of fear of its murderous reputation. It also had a powerful religious message and a claim to protect Sunnis, tapping into wide Sunni dissatisfaction with the non-Sunni regimes in both Syria and Iraq. ${ }^{1}$

This showed how porous were the regional states' "artificial" boundaries and again raised the issue of their permanence: the unmaking of the Versailles imposedWestphalian system was no longer unthinkable. The territories ruled by the Kurdish PYD and by IS, could be said to constitute "reverse quasi-states"-deprived of external sovereignty (recognition) but enjoying effective (even if temporary) internal sovereignty. However, regional states continued to fight back against these revisionist forces and in doing so enjoyed the backing of great power patrons also loath to see state-remaking or the emergence of what they considered terrorist safe havens.

\section{Debilitated Sovereignty: from competitive interference to "sphere of foreign influence"}

Sovereignty had always been jealously guarded by regional states just because it is so precarious. With state failure, external sovereignty was still technically recognized, making for classic "quasi-states" in Syria and elsewhere. Indicative of the claims of sovereignty was that international organizations could not deliver cross-border humanitarian aid to Syria without the agreement of Damascus and only through regime controlled areas until a July 2014 UNSC resolution authorized delivery to opposition controlled areas. This marked a de jure qualification of Syrian sovereignty, but de facto, it has been violated on a regular basis since it became, from at least 2012, an arena of "competitive interference" by rival outside powers backing different clients in Syria's power struggle. Not just regional powers but CIA funded operations centres in Jordan 
and Turkey financed, armed and trained proxies intervening against the internationally recognized government in Damascus and in violation of international law.

In this game of competitive interference in Syria, however, it was pro-regime Iran that held the advantage, for, as Pierret (2016) argued, as a revolutionary state it had an ideology that inspired proxies such as Hizbollah and its Iraqi avatars and experience in the organization and training of paramilitaries and in asymmetric warfare. Moreover, it was able not only to impart anti-insurgent capabilities to the Syrian army but to field militias fighting alongside it that blunted opposition momentum. Turkey and the Gulf monarchies lacked this capacity and could only provide funding, arms and, in Turkey's case, a safe-haven for Syrian exiles and this did not guarantee reliable proxies that could be coordinated against Damascus; rather, the rivalries of the anti-Asad states frustrated coordination, with the Saudis favouring the FSA and Qatar, together with Turkey, backing Islamists like Ahrar ash-Sham, Ikhwan offshoots and even radical jihadists such as al-Nusra and IS which often fought each other. Only when these external patrons agreed to set aside their differences could they impose enough unity on the opposition factions to make advances against the regime on the battlefield, as in 2015 when the jointly sponsored "Army of Conquest" captured Idlib; but this was the exception. As such, competitive interference, while bolstering the cohesion of the regime, deepened rather than overcoming the fragmentation of the opposition.

The fragmenting impact of competitive external interference seemed after 2016 to take the form of a defacto carving up of Syria into overlapping spheres of influence. The violation of Syria's sovereignty became much more overt as outside great powers were drawn in to fight IS and accelerated by their race to fill the power vacuum where IS was in retreat under air assaults. While Russian intervention was invited by the government and aimed to help Damascus re-establish its territorial control, US backed proxies such as the SDF aimed to seize Raqqa from IS for itself, an intervention characterized by Syria's UN ambassador as an "invasion" (Independent 2017). Jordanian-backed forces separately were positioning themselves to target Deir ez-Zor with its strategic oil fields and border crossing at Abu Kamal. That the US sought to prevent the Damascus government from re-establishing control over its territory was clear from its attacks on pro-government forces when they advanced toward SDF positions near Raqqa and toward the country's eastern borders at Tanf (Azizi 2017). Said the Syrian government of US warnings that it should not advance to Deir ez-Zor: "it's laughable to listen to calls asking an army of a sovereign state to stay away from its borders." In fact, the Syrian government remained in the race to Deir ez-Zor and its forces and allied Iraqi militias met up at the Syria-Iraq border (Hashem 2017); but the SDF seized key oil fields near Deir ez-Zor. As the battle with IS wound down, the US was poised to establish a semipermanent "protectorate" over PYD/SDF controlled territory in eastern Syria. At the same time, the Astana negotiations were seen to aim at a Russian-sponsored division of Syrian territory into Turkish, Jordanian, Iranian and Russian spheres of influence. Turkey was setting up police and courts in areas under its proxy control (Khatib 2017a). Russian private security firms were given concessions over mineral and energy sites if they could capture them from IS. Russia and Iran exercised unprecedented influence in regime-controlled areas (Trombetta 2017).

Competitive state re-formation: polarizing rival projects

With the division of the country into regime and opposition controlled areas, a dynamic that could be called "competitive state re-formation" emerged, with two exclusivist militarized would-be-states dominating the competition-the regime rump vs. the jihadists - that is, those best able to play the Khaldunian cards that succeed in intensive 
power struggles. The two contenders squeezed out rival projects, checked each other and, both more coercive and less inclusive than the pre-uprising regime, seemed incapable of nationalizing their governance, leading to de-facto separation along incrementally changing battle lines.

The Asad regime: The regime adapted to civil war by adopting a more violent, exclusivist and de-centralized form of neo-patrimonialism. The core-the Asad family, the security services, elite army units-represented a contraction of the top elite to its more coercive and sectarian elements as all those who had advocated compromise or power-sharing with the opposition, mostly Sunnis, such as former Vice President alSharaa, were expelled from the elite while war profiteering regime-connected crony capitalists were incorporated. This core rested on several pillars. The Alawi sect was absorbed en-mass into the army, security apparatus, and state, with some 500,000 living in Alawi suburbs of Damascus; implicated in the regime's crimes, suffering high casualties, facing an existential threat if the regime collapsed, they were the main loyalist base, potentially disaffected only when the regime failed to effectively protect them from the jihadist threat. What was hitherto a main regime pillar, the regular (cross-sectarian) Syrian army, was downsized, owing to defections and resistance to conscription. It was reconfigured for counter-insurgency and defections stopped but morale and performance remained variable. It still incorporated Sunnis who had enjoyed upward mobility through military careers, identified with the army and lived in their own military communities. As the regular army contracted, militias filled the gap, allowing pro-regime communities to assume the burden of their own self-defence: informal client networks headed by businessmen-patrons or else sectarian groups set up militias self-financed through protection rackets, extortion and pillage. The regime tried to counter the fragmentation of armed groups through their incorporation into the National Defense Forces (NDF), but the militias often remained immune to command from above; for example, Alawi militias obstructed a number of regime-attempted reconciliation deals with opposition (Sunni) towns. The regime took pains to preserve the "state" bureaucracy (salaries, services), delivering scarce resources (bread, fuel); but with the contraction of the state's revenue, its distribution function waned and access to investment and jobs began to favour loyalist areas. As the decline of the army and bureaucracy led to a decentralization of power to local fiefdoms, the resulting centre-periphery relations became as much matters of personal loyalties and bargaining (material incentives, threats, divide and rule), as of bureaucratic command, contracting regime infrastructural power. The intimate interweaving of regime forces with those of Hizbollah, Iranian revolutionary guards and Shia Iraqi militias added to the loosening of control by the regime centre and the enhanced sectarian composition of this "postBa'thist " regime. 2

Jihadist Counter States: The most effective counters to the regime were the armed Islamists movements. Their expansion was driven by a combination of sectarianism, jihadist ideology and competition for control over resources. While Islamic State (IS) and Jahbat al-Nusra were the most radical and effective, the differences in doctrine and practices between them and the likes of Ahrar ash-Sham was only a matter of degree. Their recruitment pool was the vast Sunni underclass that was subjected to regime violence and saw itself fighting for survival or without any economic alternative to employment as fighters; foreign fighters also made up a significant contingent, of IS ranks in particular. These movements, like the regime, totally eschewed political compromise, backed by external support and their command of the war economy (e.g., oil wells). Their power-building practices were broadly similar-charismatic authoritarian leadership effective in mobilizing activist followers; yet exclusionary of all those who did not accept their visions of Islam. IS, in particular, acquired some of the 
attributes of statehood, including heavy weaponry, oil resources, bureaucratic capacity, control over cities, and the ability to provide a modicum of order and welfare where it governed. However, the jihadists could not shift the balance of power against the regime owing to their endemic infighting despite the various efforts of IS and al-Nusra to impose their domination (ICG 2013: 11-15; Lund 2013).

Squeezing out civic alternatives: The local coordinating committees that organized the anti-regime protests, with discourses of Syrian civil identity based on common citizenship, morphed into local councils where regime control contracted. The councils initially had legitimacy, being either elected or self-selected by people from the region who had fought to protect it from the regime. Armed FSA groups, being local fighters, initially supported the councils and were represented on them. The councils were conceived of as an alternative government but largely failed to fulfil this function. Unable to raise funds they were dependent on funding from without. The Syrian National Council (SNC) and later the Syrian National Coalition and the Interim Government it set up were supposed to provide leadership for, deliver resources to and coordinate governance in opposition areas. Established in Turkey, this external leadership had little direct presence in Syria and little legitimacy at the grassroots. Donor resources did not sufficiently filter down to the grassroots and, the Interim Government being itself paralyzed by the rivalries of the funders to which it was beholden, with notably the Saudis and Qataris each inserting their own men, it fostered rather than ameliorated governance fragmentation.

Over time, this civic alternative was squeezed between the regime and the jihadists. As the conflict deepened and was militarized, local councils faced competition as people turned to traditional authorities, such as tribal and religious notables and armed Islamist movements insofar as these provied a modicum of security (Syrian Centre for Policy Research, 2013). Islamist groups set up parallel institutions and often attacked the councils while the regime subjected the most successful ones to bombing or siege. Marginalized by violence, and suffering from the large-scale exit of secularists from Syria and the military incompetence of the FSA, the councils shrank from 800 in 2012 to 400 in 2016, in parallel to the shrinking of their territory from $40 \%$ to $15 \%$ of the country. They survived in the local interstices between the regime and jihadists, usually in hybrid forms, wherein elements of Islamist militias and sharia courts shared power with elected councils composed of both more secular-minded activists and traditional notables (ulama, tribal leaders). Compared to the main warring sides, they were starved of resources and fragmented. In parallel, increasingly their coercive arm, the Free Syrian Army disintegrated into warlordism or turned Jihadist. ${ }^{3}$

As for the Kurdish experiment in the northeast, although touted as a new model of pluralistic multi-ethnic mass participation, with ethnic quotas in various representative assemblies, its governance is best seen as "ethnic Leninism": the more inclusive mass organizations and councils were controlled by a ruling party, the PYD, under the tutelage of PKK cadres-on-loan; repression of dissent, arrests of members of rival Kurdish parties, forced conscription---reproduced regime techniques. Instances of ethnic cleansing suggested this project may aim to maximize Kurdish ethnic purity in what had been mixed Arab-Kurdish areas (Khalaf 2016; Ali 2015).

\section{Conclusion}

The export of a flawed Westphalian states system to the global periphery was jeopardized in MENA from the outset, owing to the identity/territorial incongruity resulting from its arbitrary imposition. State building, combining historically indigenous 
"Khaldunian" techniques with imported Weberian bureaucratic institutions, resulted in neo-patrimonialism. Populist, rent funded, variants of neo-patrimonialism were initially inclusive enough to consolidate robust regimes for several decades, but went into decline as they were caught between neo-liberalization globalization, prompting a shift to more exclusionary regimes, and resistance to this from its victims. It took, however, external intervention, overt in Iraq, more covert in Syria, to translate this vulnerability into double state failure.

State failure, notably the loss of monopoly of violence by the central government and militarized civil war, unleashed renewed-and extreme-manifestations of the region's vulnerability to identity/territory incongruity: sectarian polarization, the empowerment of trans-state movements at the expense of the state, from al-Qaida to Hizbollah, the permeability, even collapse of borders, making Syria-Iraq a single space of political contestation, and the challenge to Sykes-Picot, especially by IS. State failure also spelled extreme vulnerability to proxy wars and rampant external interference culminating in the balkanization of the country into foreign spheres of influence-a descent into quasi-state semi-sovereignty. Filling the vacuum, however, were renewed forms of non-Westphalian "limited state" governance via Khaldunian practices by the rump of the Asad regime and its jihadist rivals, both less inclusive and commanding less infrastructural power than the pre-existing state, while also squeezing out more inclusive alternatives. This struggle co-existed with "heterarchy"--fragmented and overlapping jurisdictions, and a kind of Hobbesian neo-medievalism in which sovereignty was contested via the balance of violence among international, state and sub-state actors. The end (for the time being) of the Westphalian project in Syria can be seen in the extreme debilitation of both the Weberian state and of respect for Syrian sovereignty.

\section{References}

Abboud, Samer (2014), “Syria's War Economy,” Carnegie Middle East Center, 9 January, http://carnegieendowment.org/syriaincrisis/?fa $=54131$

Abboud, Samer (2016), Syria, Cambridge UK: Polity

Ali, Ali Abdul Kadir (2015) "The Security Gap in Syria: Individual and Collective Security in 'Rebel-held_Territories," Stability: International Journal of Security \& Development, $4(1)$, pp. $1-20$

Azizi, Hamidreza (2017), "US escalation in Syria strengthens Iran-Russia partnership, al-Monitor, 4 July, www.al-monitor.com/pulse/originals/2017/07/iran-russia-useastern-syria-zones-of-influence.html\#ixzz4mDwjvojk)

Bank, Andre and Thomas Richter, (2010), "Neo-Patrimonialism in the Middle East: Overview, Critique and Alternative Conceptualization," paper given at German Institute of Global and Area Studies, Hamburg 23 August, https://www.researchgate.net/publication/258325694 Neopatrimonialism in the Mid dle East and North Africa Overview Critique and Alternative Conceptualization

Barber, Benjamin R, (1995), Jihad vs. McWorld, New York: Times Books.

Bacik, Gokhan (2008), Hybrid Sovereignty in the Arab Middle East: the cases of Kuwait, Jordan and Iraq, NY: Palgrave-Macmillan. 
Baczko, A., Dorronsoro, G. \& Quesnay, A., 2013. Building a Syrian State in a Time of Civil War. Washington: Carnegie Endowment for International Peace.

Bull, Hedley and Adam Watson (1984), The Expansion of International Society, Oxford: Clarendon Press.

Bull, Hedley (1995), The Anarchical Society: A study of order in world politics, London: Macmillan, 254-55.

Bulos, Nabih, (2017), "Why thousands of Iraqi fighters have poured into Syria to aid Assad, " Los Angeles Times http://www.latimes.com/world/middleeast/la-fg-iraqmilitia-syria-snap-story.html Feb 13.

Buzan, Barry and Little, Richard (2010) "The historical expansion of international society." In: Denemark, Robert Allen, pp. 59-75, (ed.) The International Studies Encyclopedia. Chichester, UK: Wiley-Blackwell in association with the International Studies Association.

Clark, Ian (2001) "Another double movement: the great transformation after the Cold War," pp. 237-56, in Michael Cox, Tim Dunne and Ken Booth, Empires, systems and states: great transformations in international politics, Cambridge: Cambridge University Press.

Cox, Richard, (1996), 'Social Forces, State and World Orders' in Richard Cox, with Timothy Sinclair, Approaches to World Order, Cambridge: Cambridge University Press, 85-123.

DelSarto, Raffaella (2017), "Contentious Borders in the Middle East and North Africa: Concepts and Complexities," International Affairs, 93:4, 2017, 767-87

Donnelly, J. (2016). The Heterarchic Structure of Twenty-First-Century International Governance. The Korean Journal of International Studies, 14(1), 1-29.

El-Hamad, Raed (2013) "Trouble on the Border," Sada: Middle East Analysis, Carnegie Endowment, border/gfy2

Favier, Agnes (2016), "Local Governance dynamics in opposition controlled areas in Syria," pp. 6-15, in Luige Narbone, Agnes Favier, Virginie Collombier, Inside Wars: local dynamics in Syria and Libya, Florence: European University Institute

Gellner, Ernest (2006), Nations and Nationalism, Oxford: Blackwell.

Glass, Charles (2017), "How Assad is Winning," New York Review of Books, 23 February http://www.nybooks.com/articles/2017/02/23/how-assad-is-winning/ 
Hamdan, Ali Nehme (2017), "Opposition Governance and the place of borders in the Syrian Conflict," Paper given to BRISMES Conference, Edinburgh, July.

Hamlo, Khalil, (2015) Syria's 'reconciliation' deals near Collapse: Possible breakdown of truces would place Damascus under serious threat of opposition offensive. The Arab Weekly 7 31, http://www.thearabweekly.com/?id=1332

Hashem, Ali (2017) "Recapture of Iraq-Syria border point heralds new regional reality," al-Monitor, June 19, 2017, http://www.al-monitor.com/pulse/originals/2017/06/iraneastern-syria-tanf-militia-us-confrontation.html\#ixzz4kd3gY1F3

Hassan, Hassan (2014), “More than ISIS, Iraq's Sunni Insurgency, “Carnegie Endowment for International Peace: Sada, June, http://carnegieendowment.org/sada/?fa=55930

Hinnebusch, Raymond (1990) Authoritarian Power and State Formation in Ba'thist Syria: Army, Party and Peasant, Westview Press.

Hinnebusch, Raymond (2010), "Toward a Historical Sociology of State formation in the Middle East," Middle East Critique, 19:3. 201-216.

Hinnebusch, Raymond (2012), "Syria: from Authoritarian Upgrading to Revolution?" International Affairs, January.

Hinnebusch, Raymond, Omar Imady and Tina Zintl (2015) "Civil Resistance in the Syrian Uprising: From Democratic Transition to Sectarian Civil War" pp. 223-47, in Adam Roberts, Michael Willis and Timothy Garton Ash, eds., Civil Resistance in the Arab Spring: Triumphs and Disasters, 2011-14, Oxford: Oxford University Press.

International Crisis Group (ICG) (2013) "Anything But Politics: the State of Syria's Political Opposition," Middle East Report, October

Independent (2017) "Raqqa Offensive to Begin in Days," (http://www.independent.co.uk/news/world/middle-east/raqqa-syria-battle-civilwar-isis-coalition-rebels-un-ambassador-french-a7648986.html

Itani, Fidaa (2014) "Roots and Futures of al-Qaida Offshoots in Syria," Knowledge Program Civil Society in West Asia, Special Bulletin 6, September.

Jackson, Robert H. (1993) Quasi States: Sovereignty, International Relations and the Third World, Cambridge: Cambridge University Press. 
Kaldor, Mary (2005) "Old Wars, Cold Wars, New Wars and the War on Terror, International Politics, 42: 491-08.

Kamrava, Mehran (2014) Fragile Politics, Weak States in the Greater Middle East, Center for International and Regional Studies, Georgetown School of Foreign Service in Qatar.

Khaddour, Kheder (2015a) “The Assad Regime's Hold on the Syrian State,"

Carnegie Middle East Center, July 8, http://carnegie-mec.org/2015/07/08/assadregime-s-hold-on-syrian-

state $/$ id3k?utm source $=$ Sailthru\&utm medium $=$ email\&utm term $={ }^{*}$ Situation $\% 20$ Repor t\&utm campaign $=$ SitRep 0708

Khaddour, Kheder (2015b), Assad's Officer Ghetto: Why the Syrian Army Remains Loyal", Carnegie Middle East Center, November 4,

Khalaf, Rana (2015), "Governance without Government in Syria: Civil Society and State Building during Conflict, Syria Studies 7: 3, 37-72, https://ojs.standrews.ac.uk/index.php/syria/article/view/1176/911

Khalaf, Rana (2016), Governing Rojava: Layers of Legitimacy," Chatham House Research Paper, December

Khatib, Khaled (2017a), "Free Syrian Army getting backup from Turkish-trained police," Al-Monitor, 23 March.

Khatib, Khaled, (2017b), "Border crossings bring in cash for Free Syrian Army factions," Al-Monitor, 28 September

Knights, Michael (2012), "Syria's Eastern Front: The Iraq Factor," Washington Institute Policywatch, July 6, http://www.washingtoninstitute.org/policy-analysis/view/syriaseastern-front-the-iraq-factor

Krasner, Stephen D (1999), Sovereignty: Organized Hypocrisy, Princeton NJ: Princeton University Press

Legrand, Felix (2016), "Foreign Backers and the Marginalization of the Free Syrian Army," Arab Reform Initiative, November. 
Lawson, Fred, (2014), "Implications of the 2011-2013 Syrian Uprising for the Middle Eastern Regional Security Complex," Center for International and Regional Studies, Georgetown Qatar School of Foreign Service

Lund, Aron (2013) "The Non-State Militant Landscape in Syria," Combating Terrorism Center at West Point, August 27, https://ctc.usma.edu/posts/the-non-state-militantlandscape-in-syria

Lund, Aron, (2015) "Who are the pro-Asad Militias?", Carnegie Middle East Center, March 2, http://carnegie-mec.org/diwan/59215?lang=en

Lund, Aron (2017a) "Syria: East Ghouta Turns on Itself, Again," https://tcf.org/content/commentary/syria-east-ghouta-turns/, The Century Foundation, 1 May.

Lund, Aron, (2017b) Black Flags over Idlib: The jihadi power grab in northwestern Syria," 9 August.

Lustik, Ian, (1997) "The Absence of Middle East Great Powers: Political 'Backwardness in Historical Perspective," International Organization, 51:4, Autumn, 653-683.

McGinty, Roger. (2011). International Peacebuilding and Local Resistance: Hybrid Forms of Peace. Hampshire: Palgrave Macmillan.

Meyer, John W; John Boli; George M Thomas \& Francisco O Ramirez (1997). "World Society and the Nation-State". American Journal of Sociology. 103 (1): 144-181.

Newman, Edwin (2009), "Failed states and international order: constructing a postWestphalian world," Contemporary Security Policy 30:3, December 2009, 421-43.

Pierret, Thomas, (2016) "State Sponsors and the Syrian Insurgency: the limits of foreign influence," in Luige Narbone, Agnes Favier, Virginie Collombier, Inside Wars: local dynamics in Syria and Libya, Florence: European University Institute

Posen, Barry (1993) "The Security Dilemma and Ethnic Conflict," Survival, 35, no. 1 (Spring).

Risse, Thomas, (ed.) (2013), Governance without a state?: policies and politics in areas of limited statehood. Columbia University Press, New York.

al-Salhy, Suadad (2012) , "Scores of Iraqi Shia militants are fighting in Syria..." Reuters October 16. 
Samaha, Nour, (2017), "Survival is Syria's Strategy," Report Syria, The Century Foundation, Feb 8, https://tcf.org/content/report/survival-syrias-strategy/

Smith, Anthony. (1981), "States and Homelands: the Social and Geopolitical Implications of National Territory," Millennium, 10, autumn.

Smyth, Philip (2015), "The Shiite Jihad in Syria and its Regional Effects," Washington Institute, Policy Focus 138.

Stanfield, Gareth (2013), The Remaking of Syria, Iraq and the Wider Middle East, RUSI Briefing Paper, July.

Syrian Centre for Policy Research (2013) The Syrian Catastrophe: Socioeconomic Monitoring Report First Quarterly Report (January - March 2013), Damascus: UNRWA.

Tamimi, Ayman Jawad (2015), “Shia Militias in Iraq and Syria," Rubin Center, July 29, http://www.rubincenter.org/2015/07/shii-militias-in-iraq-and-syria/

Tamimi, Ayman Jawad (2017), Reconciliation' in Syria: The Case of Al-Sanamayn, SyriaComment, April 27

Todman, Will (2016), “Sieges in Syria: Profiteering from Misery,” Middle East Institute Policy Focus Series, 14, June.

Turkmani, Rim (2015) "ISIL, JAN and the War Economy in Syria, London School of Economics, $\quad 30 \quad$ July; $\quad$ http://www.securityintransition.org/wpcontent/uploads/2015/08/ISIL-JAN-and-the-war-economy-in-Syria1.pdf

Trombetta. Lorenzo (2017), “How the 'De-Escalation Zone' Plan Benefits Syria's Foreign Players," Baladi News May. 17, https://www.baladi-news.com/en/news

Vignal, Leila (2017), "The Changing borders and borderlands of Syria in a time of conflict," International Affairs, 93:4, 2017, 809-27.

Waltz, Kenneth (1979), Theory of International Politics, Boston: Addison-Wesley, pp. 127-28

Wehrey, Frederic (2014) "To beat ISIS, exploit its contradictions," Carnegie Endowment for International Peace, June 17, http://carnegieendowment.org/2014/06/17/to-beatisis-exploit-its-contradictions-pub-55936

Weulersse, Jacques (1946) Paysans de Syrie et du Proche-Orient. Paris: Gallimard.

Yaziji, Jihad (2014), Syria's War Economy," ECFR, April.

Zartman, I. William (2017), "States, boundaries and sovereignty in the Middle East: unsteady but unchanging, International Affairs, 93:4, 937-48. 

${ }^{1}$ Analysis based on Hassan 2014; Wehrey 2014, Itani 2014.

2 This analysis is based on: ICG 2013; Lund 2015; Samaha 2017; Khaddour 2015a; Khaddour 2015b; Yaziji 2014.

3 This analysis is based on: Baczko, A., Dorronsoro, G. \& Quesnay, A., 2013. Khalaf 2015; Legrande 2016; Favier 2016; Ali 2015; Yazigi 2014; 